\title{
GIS-Based Urban Flood Risk Assessment and Management-A Case Study of Delhi National Capital Territory (NCT), India
}

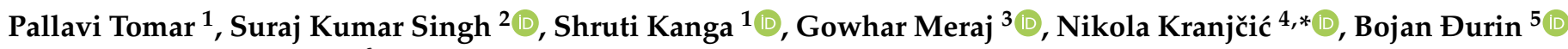 \\ and Amitanshu Pattanaik ${ }^{6}$ \\ 1 Centre for Climate Change and Water Research, Suresh Gyan Vihar University, Jaipur 302017, India; \\ pallavi.49382@mygyanvihar.com (P.T.); shruti.kanga@mygyanvihar.com (S.K.) \\ 2 Centre for Sustainable Development, Suresh Gyan Vihar, Jaipur 302017, India; \\ suraj.kumar@mygyanvihar.com \\ 3 Department of Ecology, Environment and Remote Sensing, Government of Jammu and Kashmir, \\ Srinagar 190018, India; gowharmeraj@gmail.com \\ 4 Faculty of Geotechnical Engineering, University of Zagreb, Hallerova Aleja 7, 42000 Varaždin, Croatia \\ 5 Department of Civil Engineering, University North, 42000 Varaždin, Croatia; bojan.durin@unin.hr \\ 6 Defence Geoinformatics Research Establishment, Defence Research \& Development Organisation, \\ Ministry of Defence, Chandigarh 160036, India; amitansu@yahoo.com \\ * Correspondence: nikola.kranjcic@gfv.unizg.hr
}

check for updates

Citation: Tomar, P.; Singh, S.K.; Kanga, S.; Meraj, G.; Kranjčić, N.; Đurin, B.; Pattanaik, A. GIS-Based Urban Flood Risk Assessment and Management-A Case Study of Delhi National Capital Territory (NCT), India. Sustainability 2021, 13, 12850. https://doi.org/10.3390/su132212850

Academic Editors: Gyan Chhipi Shrestha, Nicolas Beauchamp and Ianis Delpla

Received: 13 October 2021

Accepted: 17 November 2021

Published: 20 November 2021

Publisher's Note: MDPI stays neutral with regard to jurisdictional claims in published maps and institutional affiliations.

Copyright: (c) 2021 by the authors. Licensee MDPI, Basel, Switzerland. This article is an open access article distributed under the terms and conditions of the Creative Commons Attribution (CC BY) license (https:/ / creativecommons.org/licenses/by/ $4.0 /)$.

\begin{abstract}
Urban floods are very destructive and have significant socioeconomic repercussions in regions with a common flooding prevalence. Various researchers have laid down numerous approaches for analyzing the evolution of floods and their consequences. One primary goal of such approaches is to identify the areas vulnerable to floods for risk reduction and management purposes. The present paper proposes an integrated remote sensing, geographic information system (GIS), and field survey-based approach for identifying and predicting urban flood-prone areas. The work is unique in theory since the methodology proposed finds application in urban areas wherein the cause of flooding, in addition to heavy rainfall, is also the inefficient urban drainage system. The work has been carried out in Delhi's Yamuna River National Capital Territory (NCT) area, considered one of India's most frequently flooded urban centers, to analyze the causes of its flooding and supplement the existing forecasting models. Research is based on an integrated strategy to evaluate and map the highest flood boundary and identify the area affected along the Yamuna River NCT of Delhi. In addition to understanding the causal factors behind frequent flooding in the area, using field-based information, we developed a GIS model to help authorities to manage the floods using catchment precipitation and gauge level relationship. The identification of areas susceptible to floods shall act as an early warning tool to safeguard life and property and help authorities plan in advance for the eventuality of such an event in the study area.
\end{abstract}

Keywords: Yamuna river; urban flood management; warning tool; decisional support system (DSS)

\section{Introduction}

Flooding is considered one of the most catastrophic disasters because of its magnitude of devastating impacts on overall human well-being [1,2]. It contributed to about $39.26 \%$ of worldwide natural disasters and caused USD 397.3 billion worth of damage between 2000 and 2014 [3,4]. Human activities such as urbanization, deforestation, and unplanned development all contribute towards the rise in the number of areas vulnerable to floods [3-5]. Moreover, the changing climate that has manifested the increase in the frequency of extreme precipitation events is also one of the primary forces behind the exacerbated flooding problem [6,7].

The limited capacity of river canals, human populations in low-lying areas, and rapid increase in human settlements without improving draining infrastructure have mainly 
contributed to urban floods [8]. Due to the recurrency of this hazard, particularly in urban centers and its impact on local, regional, and global economies, the need for an efficient flood modeling approach to preventing them has become a necessity [9-11].

A comprehensive flood management strategy requires an understanding of its underlying causes by assessing the physio-climatic and hydrodynamic parameters as well as damage and exposure indices related to socioeconomic and ecological parameters [3-5,12]. The overall output of this exercise is finally the calculation of the flood risk that integrates hazard and vulnerability in assessing the latter's accumulation and propagation. The flood risk analysis is exceedingly complex and challenging in developing countries, primarily because of the data limitations [5]. An assessment of the spatial exposure to floods is the primary requirement for devising an early warning system [13]. Different methodologies have been developed to determine the extent and impact of floods. The data type, processing methods, and spatial representation govern the most appropriate method for a specific flooding phenomenon [14,15]. Geographic information systems (GIS), geostatistical approaches, and satellite remote sensing (RS) have been at the forefront of these methodologies to calculate risk, hazard, and vulnerability to floods [16,17]. Collectively, RS and GIS form the backbone of almost all the earth system modeling approaches [18,19].

Modeling is required for planning efficient and effective flood risk management to face the challenges of a diverse set of hazard and disaster situations [20-22]. Moreover, the foundation of a comprehensive flood management plan is based on mapping vulnerable areas. Only once that is accomplished can various structural (such as dykes, spurs, detention basins, and reservoirs) and non-structural (such as land-use planning, restoration of wetlands, and compensation policy) measures to lessen the damage caused by floods be efficiently formulated and employed.

In India, many flood modeling studies have been carried out to understand the evolution of floods in order to manage the floods effectively. To understand the magnitude of damage to bridges during floods, Mazumdar (2009) evaluated hydrologic, topographic, and morphological characteristics of rivers to derive a relationship between the damage and exposure [23]. Pramanik et al. (2010) used observational cross-sectional data of the Brahmani River basin in eastern India to simulate the extent of floods using a hydrodynamic modeling approach [24]. Similarly, Timbadiya et al. (2012) simulated the floods in the lower Tapi river using a similar hydrodynamic modeling setup [25]. The work assessed the sensitivity of Manning's coefficient on the coastal flood plain of the study area and calibrated a one-dimensional hydrodynamic model for Manning's coefficient to set up the model for flood forecasts. Similarly, Doiphode and Ravindra (2012) focused on timevarying roughness updates to mimic flows through natural channels using quasi-steady dynamic wave and full-dynamic wave theory to solve Saint Venant's equation in the hydraulic flood routing model [26]. A similar study was carried out by Sankhua et al. (2012) in the Krishna River's Karad—Kurundwad reach [27]. Further, Vijay et al. (2007) demonstrated the working and functioning of the hydrodynamic model used to determine the degree of inundation vis-à-vis different developmental scenarios in the basin. Although the model worked on default parameters, the results provided insights about possible inundations in the eventuality of flood disasters in the stretch of the Yamuna river [28].

For the national capital region of Delhi, India, several flood assessment studies have been carried out. Vijay et al. (2009) provided a hydrodynamic simulation of the Yamuna River under several defined flood flows to determine land availability under existing and modified riverbed geometry, including channel dredging and riverbed dressing [29]. Husain (2018) outlines the approach for flood peak estimation at Hathinkund and Okhla barrages on the Yamuna River [30]. Kumar et al. (2018) show how they used the POT technique to estimate floods with varied return periods. The primary goal of this study was to create a hydrodynamic model for flood simulation in the Delhi segment of the Yamuna River to determine how vulnerable the hydraulic infrastructure in the Delhi segment of the Yamuna River is to floods [31]. Flood management measures for the national capital region of Delhi, India, are described to some extent by Kumar et al. (2019) [32]. To date, the 
use of the maximum possible gauge level scenario-a concept that defines the maximum inundate area under the maximum flooding scenario in Delhi NCT-has not been carried out. The mapping of the maximum area under flooding shall help the authorities to develop comprehensive management and mitigation strategy for the Delhi NCT-the focus of the present study.

India is one of the world's most flood-prone countries, with 113 million people exposed to floods. According to a UN report, India's average annual economic loss due to disasters is estimated to be USD 9.8 billion, out of which more than USD 7 billion of the loss is due to floods [33]. Being one of the most urbanized cities in the country, Delhi is always at high risk of urban flooding. The rate of urbanization can be gauged from the fact that the built-up area increased by seven times between the 1970s and 2000s. During this period, as per the Delhi government's historical data for floods available for Delhi, 1978 saw the worst flood ever when the water level reached $207.49 \mathrm{~m}$, with danger level marked as $204.83 \mathrm{~m}$ and discharge of 2.53 lac cusecs at the Old Railway Bridge. Out of this, 7.0 lac cusecs of water was released from the Tajewala Barrage, which inundated around 130 villages and 25 urban colonies in Delhi [34-38]. Tajewala is the main barrage that is used by the Department of Irrigation and Flood Control (I\&FC), Government of Delhi to regulate the Yamuna waters entering Delhi NCT.

The critical analysis of the flood zoning pattern reveals that the high-risk zones are the areas that have earlier been identified as unplanned or poorly planned areas having high population densities and sub-standard housing structures [38]. These include areas of North Delhi and the Trans-Yamuna Area. Some of the colonies that have come up in these areas are at 3 to $4 \mathrm{~m}$ below the 1978 flood levels. The community exposed to the highest risk from floods comprises the families living in the villages and unauthorized colonies within the riverbed. There are over 15,000 such families, having over 75,000 persons situated on the wrong side of the embankments. These people live on the edge of the floods and are the first ones to find their homes washed away [39-42]. In terms of monetary losses, in the 1978 flooding event, the total damage to crops, houses, and public utilities was estimated at Rs. 176.1 million. In 1988, floods affected approximately 8000 families. In 1995, floods rendered about 15,000 families homeless. In 2013, around 10,000 people were evacuated due to rising water levels and shifted to tents set up at safer places. The worst-affected areas include Old Railway Bridge, Akshardham, Geeta Colony, Okhla, Garhi Mandu, Madanpur Khadar, and Usmanpur [43-48].

The present study focused on developing an integrated approach using a geographic information system (GIS) and field-based approach to map the maximum flood extent in the eventuality of the highest surge in the flood levels measured at the Old Delhi Railway gauging station. This is the primary early flood warning gauging station for the whole Delhi NCT downstream. The study also developed a forecasting regression model based on gauge level and time series precipitation data in the Yamuna River National Capital Territory (NCT) of Delhi to assist the existing flood warning system of the Delhi NCT. The approach used in this study is very significant as the primary cause of the flooding in the study area is not precipitation alone but the inefficient urban drainage of the study area of the Delhi NCT. Therefore, using hydrodynamic models such as HEC-RAS alone has not proved sufficient as an early warning model. It needs to be supplemented with the GIS-based approach presented in this study to understand the maximum extent of the flood to warn the maximum number of people affected in the eventuality of an extreme flooding event.

\section{Materials and Methods}

The Delhi NCT, occupying an area of $1483 \mathrm{sq} \mathrm{km}$., lies between latitudes $28^{\circ} 24^{\prime} 15^{\prime \prime}$ and $28^{\circ} 53^{\prime} 00^{\prime \prime} \mathrm{N}$ and longitudes $76^{\circ} 50^{\prime} 24^{\prime \prime}$ and $77^{\circ} 20^{\prime} 30^{\prime \prime} \mathrm{E}$ with an average elevation of $233 \mathrm{~m}$ (ranging from 213 to $305 \mathrm{~m}$ ) above the mean sea level (Figure 1). As per the 2011 census, Delhi NCT has three statutory towns, 110 census towns, and 112 villages. The population of Delhi has increased at a rate of $2.1 \%$ per annum during the decade from 
2001 to 2011. Delhi ranks first in terms of population (13.8 million), whereas Lakshadweep, with 60,650 people, has the lowest population among union territories (Figure 2). Delhi's population has grown from a meager 405,800 in 1901 to a staggering 16,753,200 in 2011, making it one of the largest growing cities in the world [49]. The Delhi region received the maximum share of foreign direct investment (FDI) compared to other states [50]. This allowance of $100 \%$ FDI in real estate and infrastructure by the Indian government has made Delhi susceptible to rapid urban growth [51]. Consequently, agricultural and allied activities have reduced output from the primary sector of Delhi's economy.
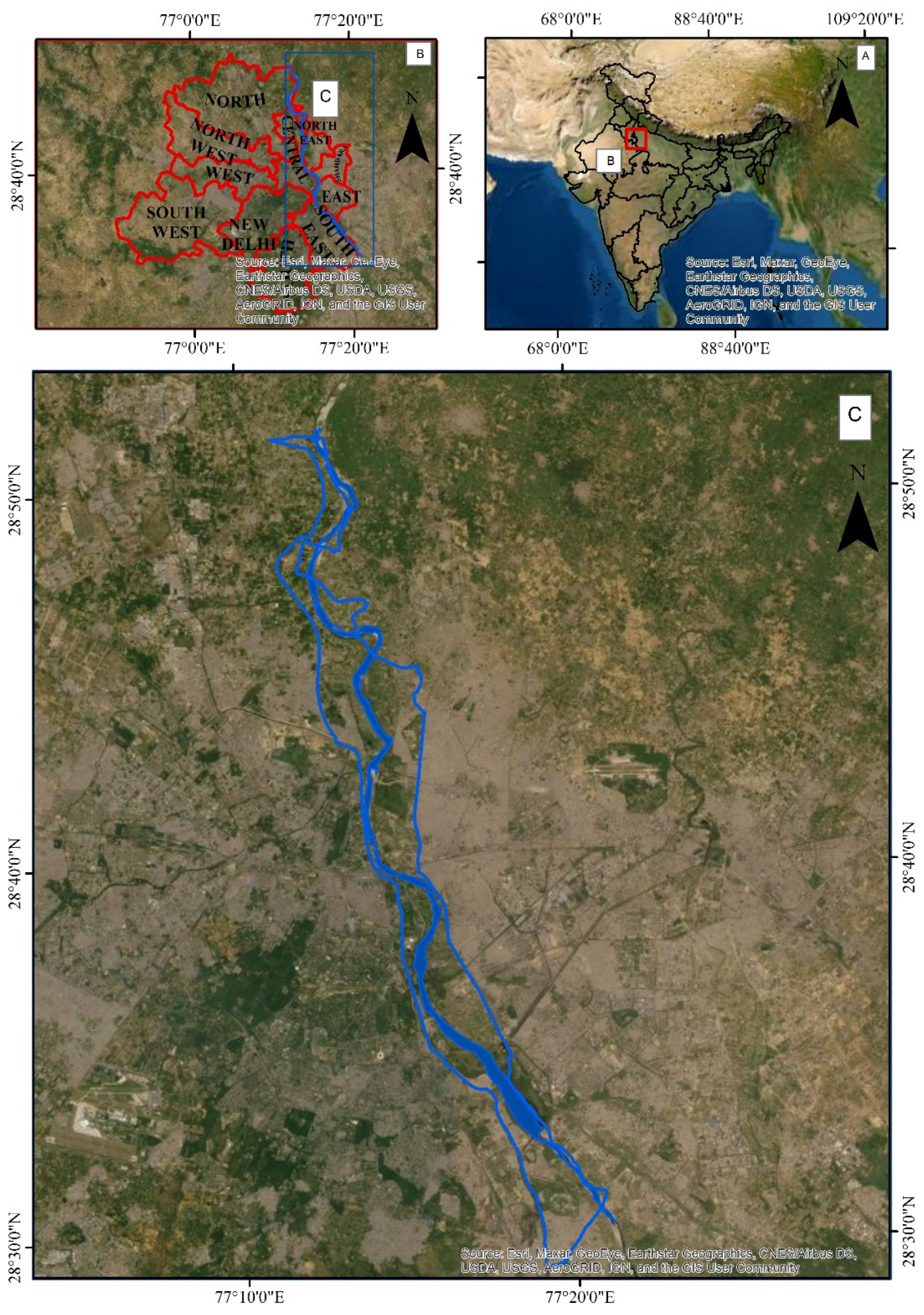

Figure 1. Study area map Delhi NCT (National Capital Territory) (B) with respect to India (A), and floodplain of NCT Delhi (C). 
This predominant shift from agriculture to urban work services created abundant job opportunities that have attracted people from different states to search for employment [52]. The cultural model of elitism is yet another factor that attracts people to the city [53]. These factors have exacerbated the recurrent flooding phenomenon in the region that damages properties, human lives, and the environment.

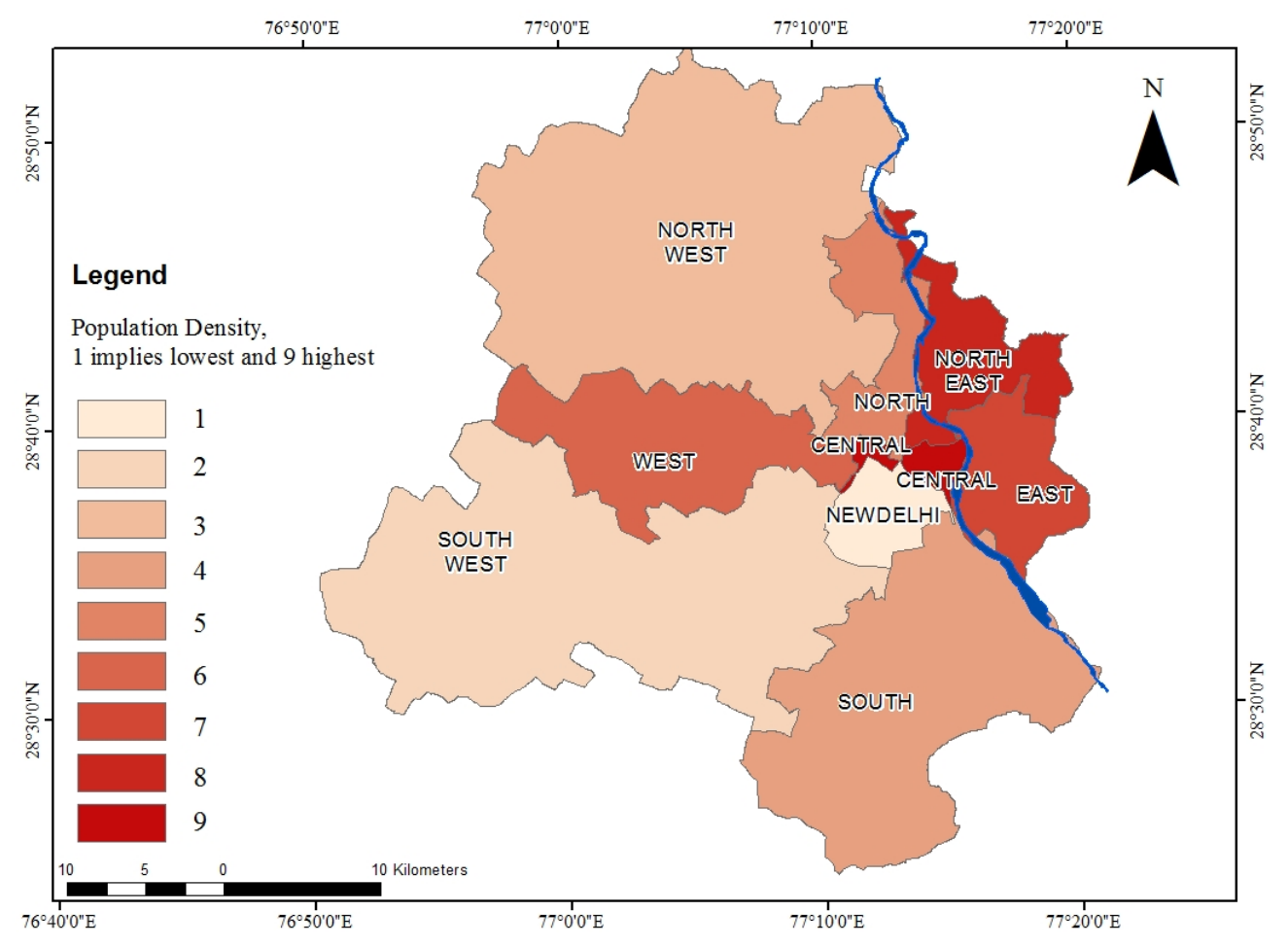

Figure 2. Population density map of Delhi NCT (revised).

Delhi can be divided into three major drainage basins, ultimately discharging into the Yamuna River: Najafgarh, Barapulaah, and Shahdara basins. The Delhi NCT is prone to flooding from the Yamuna river, which has a catchment in Haryana, and the Sahibi River (Rajasthan) via the Najafgarh drain.

The Yamuna River enters Delhi from the northeast near Palla at an altitude of $210.3 \mathrm{~m}$, and, after a traverse of about $40 \mathrm{~km}$, it leaves Delhi at an altitude of $198.12 \mathrm{~m}$ near Jaitpur in the south. Nearly every year, there is flooding in the Yamuna River, the intensity of which may be low, medium, or high according to the classification set up by the Irrigation and Flood Control Department, Delhi Government (I\&FC). According to the I\&FC department, it is a low flood when the gauge levels are below $204.22 \mathrm{~m}$. Between $204.22 \mathrm{~m}$ and $205.44 \mathrm{~m}$, floods are classified as medium, and above $205.44 \mathrm{~m}$, floods are classified as a high category. The water level of Yamuna in summers is found to be nearly $201.0 \mathrm{~m}$. During this type of flood, the water generally remains within its regime, and no danger is created to life and property and is thus referred to as the low category. The floods that reach the water level between $203.0 \mathrm{~m}$ and $206.44 \mathrm{~m}$ are considered medium category floods; the water spreads out of the regime and touches the embankments constructed on both sides (Table 1). The floods hitting the Yamuna River in 1967, 1971, 1975, 1976, 1978, 1988, 1995, 1998, 2010, 2013, and 2018 have been the major ones reaching a water level of $206.0 \mathrm{~m}$ or more and thus have been classified as high category floods [32]. 
Table 1. Flood level locations at various gauging sites of the Yamuna River.

\begin{tabular}{ccc}
\hline Site Number & Location Name & Actual Flood Level Value $^{\mathbf{1}^{\mathbf{2}}}$ \\
\hline 1 & Palla Village & $212.30 \mathrm{~m}$ \\
2 & Jhangola Village & $211.15 \mathrm{~m}$ \\
3 & Jagatpur Bund & $209.35 \mathrm{~m}$ \\
4 & Wajirabad Barrage & $208.05 \mathrm{~m}$ \\
5 & Old Delhi Railway Bridge & $207.11 \mathrm{~m}$ \\
6 & Yamuna Barrage & $205.06 \mathrm{~m}$ \\
7 & Okhla Barrage & $200.10 \mathrm{~m}$ \\
8 & Jaitpur Village & $198.07 \mathrm{~m}$ \\
\hline
\end{tabular}

${ }^{1}$ Flood level value obtained from I\&FC Department for the year 2013.

For generating the land use land cover (LULC) information map for the Delhi NCT, we used a Worldview-2 multispectral satellite image, Dated 21 September 2015. Further, a high-resolution, 1-m digital elevation model (DEM) was developed using Cartosat stereo pair data ( $2.5 \mathrm{~m}$ spatial resolution). Both of these datasets were procured from the National Remote Sensing Center, Indian Space Research Organization, Hyderabad (NRSC, ISRO) and were already pre-processed for radiometric and geometric corrections. A high-resolution DEM is essential for flood zonation mapping based on gauge level heights. DEM was generated using ERDAS-IMAGINE OrthoBASE Pro software-a standard image processing and GIS software suite [54,55].

Land use land cover (LULC) information is vital for understanding the evolution and management of floods. After analyzing the available ground truth information, it was decided that categories of specific LULC types should be selected to ensure that accurate mapping could be performed. Using the visual image interpretation technique at 1:1000 scale, we classified the image into the following categories: water, forest, agriculture, recreational park, open-land, and built-up [56]. The LULC was validated using groundtruthing. Using spot height procedure and embankment information, we generated the potential flood-affected region under the maximum possible gauge levels at the Old Delhi Railway gauge station (Figure 3). The overall methodology used in the present study is shown in Figure 4.

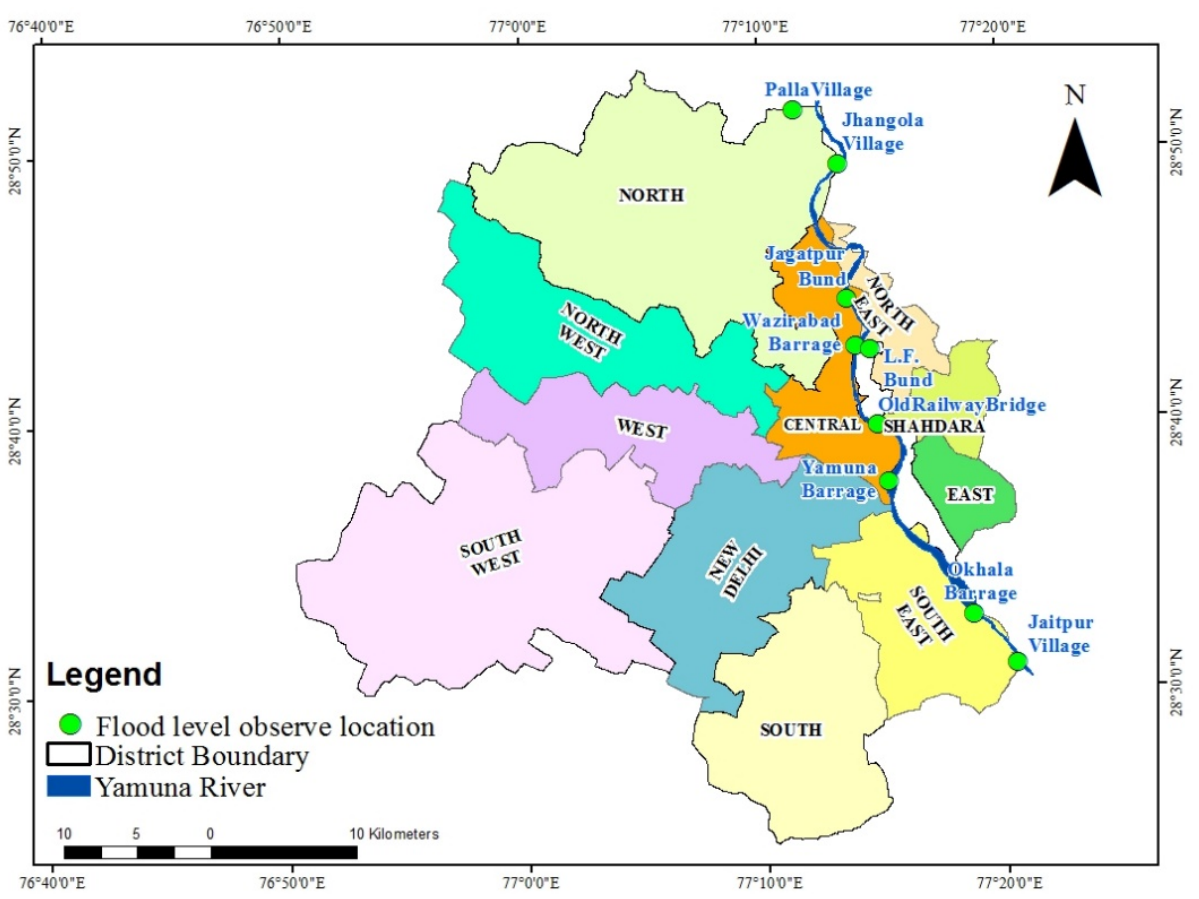

Figure 3. Map of observed flood level locations at the Yamuna River NCT of Delhi (revised). 


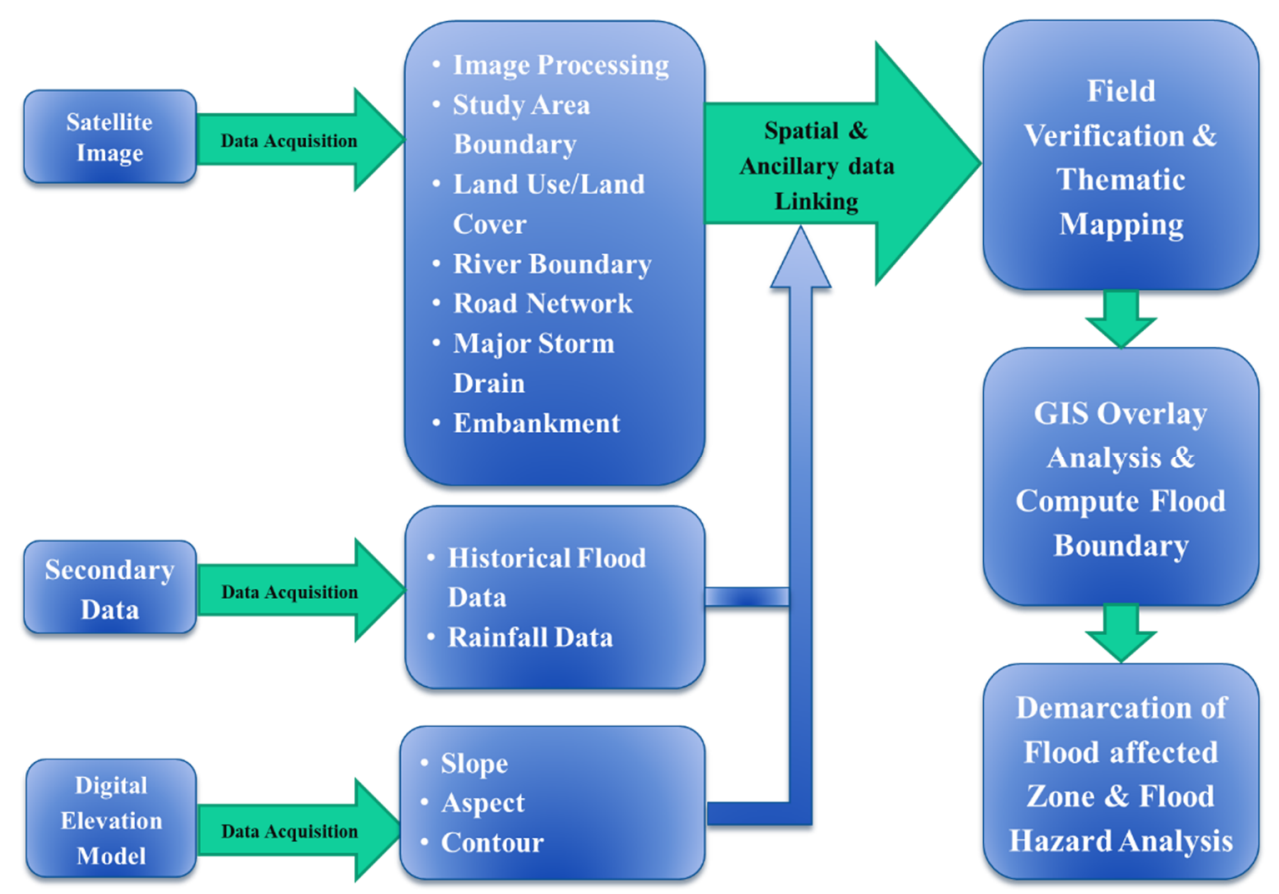

Figure 4. Methodology flowchart used to assess the maximum inundated area under worst-case flooding scenario.

\section{Results and Discussion}

Disasters wreak havoc on life, property, and overall human well-being [ 57,58$]$. Years of economic development and infrastructural assets are washed off with every flooding event, particularly in the developing countries of Southeast Asia, such as India, Pakistan, and Bangladesh [59-63]. The difference between the developed and developing worlds in the case of managing floods lies in their complex differential socioeconomic setups [64-68]. Moreover, many disasters are localized in nature having a lesser spatial extent of the damage. However, the flood is spatially an extensive nature's fury [69]. Hence, to manage and mitigate floods in the developing world, each aspect of this phenomenon must be understood. While hydrodynamic models such as HEC-RAS work fine in the United States, it fails to provide promising results in many parts of the Indian subcontinent mainly because of the non-availability of the basic modeling parameters [70-74]. Therefore, an out-of-box approach is usually devised by the researchers to solve such problems. Using a remote sensing, GIS, and field-based approach, the present study tried to feed the current flood management plan of the Delhi NCT with the spatial extents of the maximum flood inundation.

The results show that most of the downstream sections of the catchment and the various land uses in these areas are at high levels of flood risk. Delhi NCT has an average elevation of $233 \mathrm{~m}$ (ranging from 190 to $313 \mathrm{~m}$ ) above the mean sea level (Figure 5). The elevation map of the study area shows that the southern parts of the region are at higher elevation levels than the eastern and northern parts. The flood plains of Yamuna exhibit much lower elevations. The South Delhi part has a higher elevation, and the East Delhi part is near the Yamuna. 


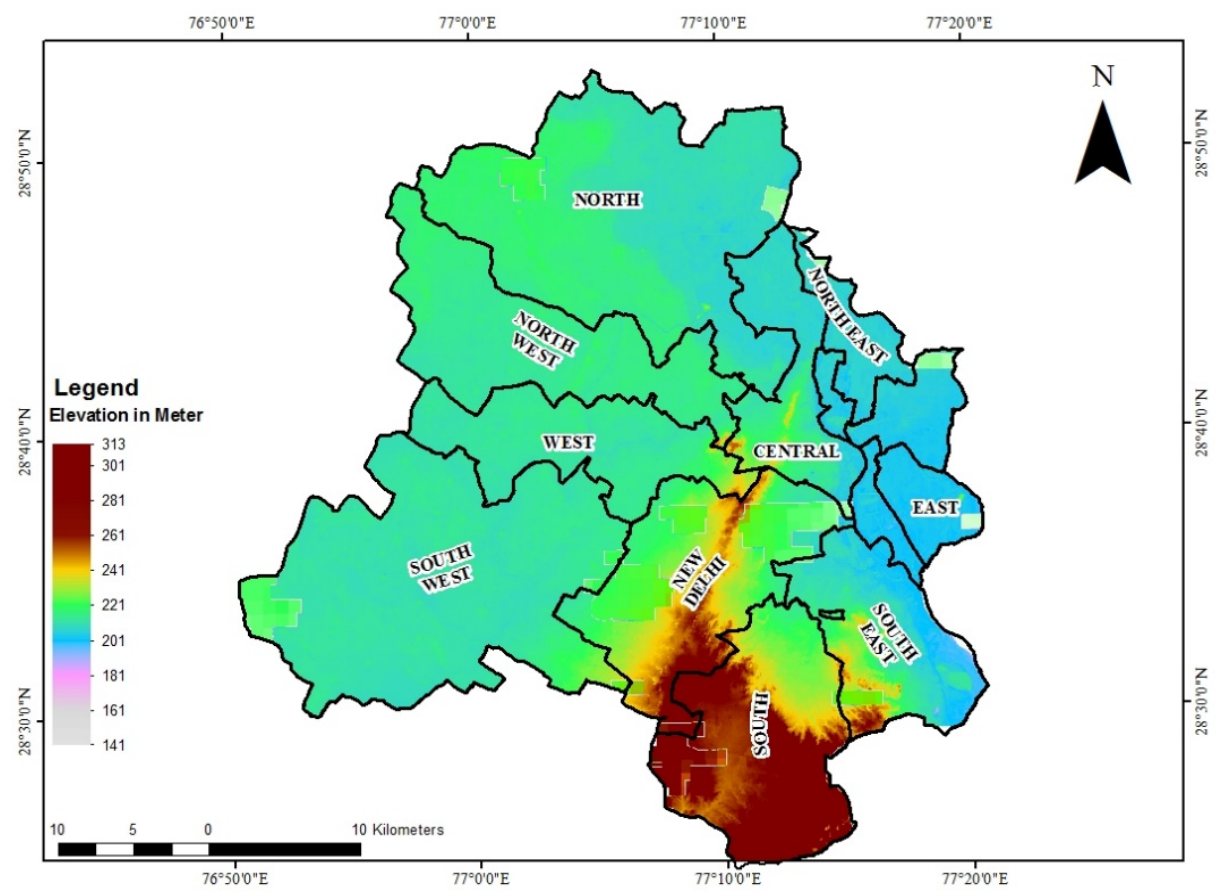

Figure 5. Digital elevation model of the NCT of Delhi (Revised).

The area under different LULC categories of the study area, i.e., agriculture, river and water bodies, gardens and parks, and open lands, are shown in Table 2. The Delhi NCT region is urbanized, with approximately $15 \%$ of the total area contributing to built-up land use, as shown in Figure 6, Table 2. The land use/land cover indicated that built-up comprises $164.13 \mathrm{sq} \mathrm{km} \mathrm{(15.32 \% ),} \mathrm{open} \mathrm{land} 252.82 \mathrm{sq} \mathrm{km} \mathrm{(23.59 \% ),} \mathrm{parks} 70.64 \mathrm{sq} \mathrm{km}$ $(6.59 \%)$, water bodies $2.04 \mathrm{sq} \mathrm{km}(0.19 \%)$, forest $131.35 \mathrm{sq} \mathrm{km}(12.26 \%)$, and agriculture (450.69 sq km, (42.05\%).

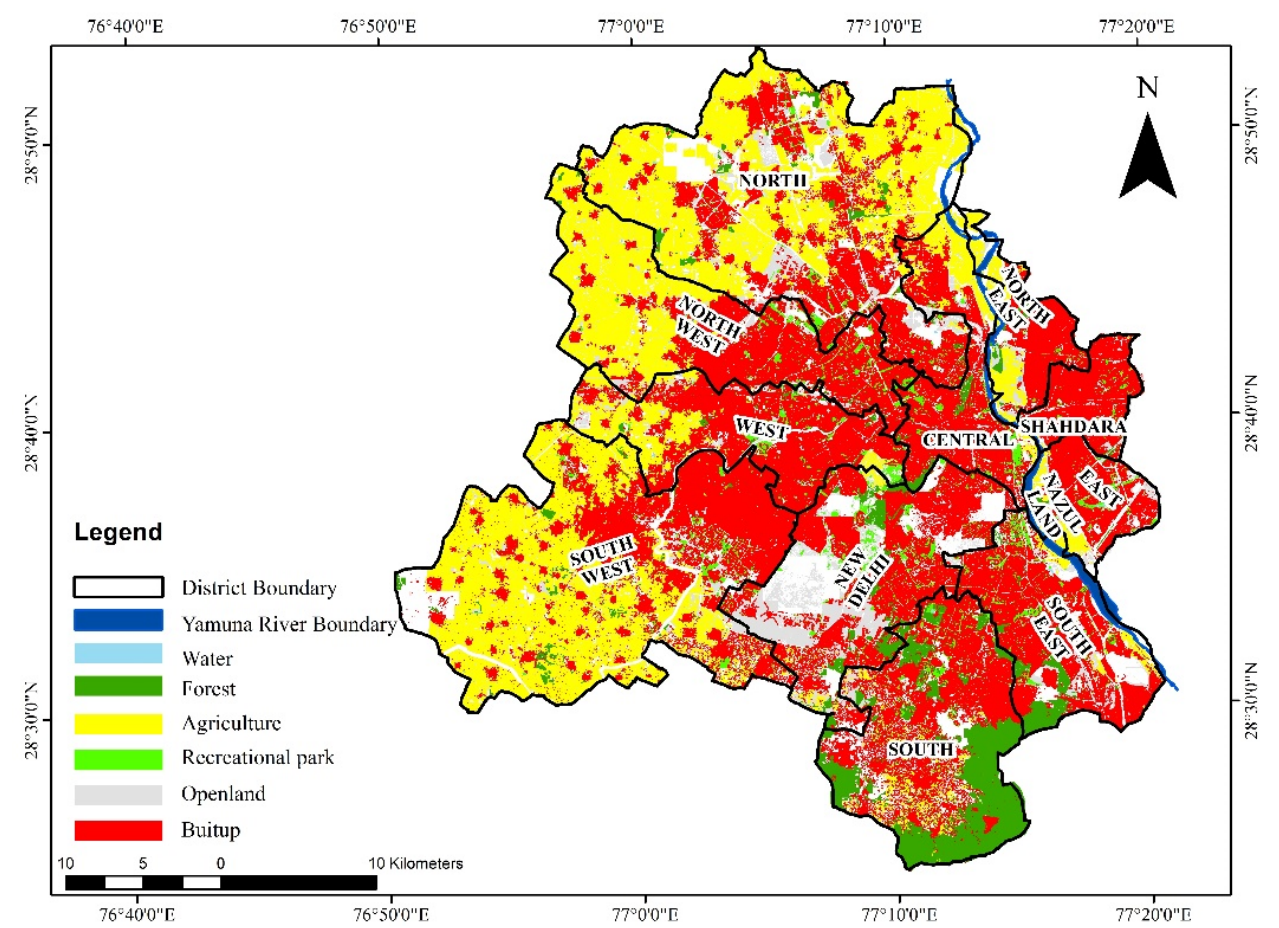

Figure 6. Land use and land cover map of study area (revised). 
Table 2. Area under different land use and land cover in the Delhi NCT as of 2015.

\begin{tabular}{cccc}
\hline S. No. & Class Name & Area $\left.\mathbf{( k m}^{\mathbf{2}}\right)$ & Percentage \\
\hline 1 & Cultivation land & 450.69 & 42.05 \\
2 & Forest & 131.35 & 12.26 \\
3 & Water Bodies & 2.04 & 0.19 \\
4 & Parks & 70.64 & 6.59 \\
5 & Open Land & 252.82 & 23.59 \\
6 & Built up & 164.13 & 15.32 \\
\hline
\end{tabular}

According to the estimates of Jain et al. (2016), the built-up percentages of the Delhi region increased from $7.67 \%$ of the total area in 1977 to $38.28 \%$ percent of the total area in 2014 (Figure 7). Similarly, the area under cultivable land decreased from $44.66 \%$ in 1977 to $21.91 \%$ in 2014 [75]. These area estimates are for the whole Delhi region, whereas Table 2 shows the area estimates under different LULC categories for Delhi NCT alone. Nonetheless, it is clearly visible that there is an enormous increase in the impervious surfaces in the Delhi region, which is one of the causes of an increase in the area exceedingly vulnerable to floods [75]. The number of flooding events from 1965 until 2019, according to the three IF\&C category floods, are presented in Table 3 and Figure 8. It can be seen that, although the number of flooding events has almost remained the same in various decades, the damage caused has increased manifold. As shown in Figure 8, there has been a tremendous increase (nearly $400 \%$, or 4 -fold) in the urbanized area in Delhi [75]. It has created an entirely different scenario for the authorities to mitigate and manage the recurring flooding events in the capital.

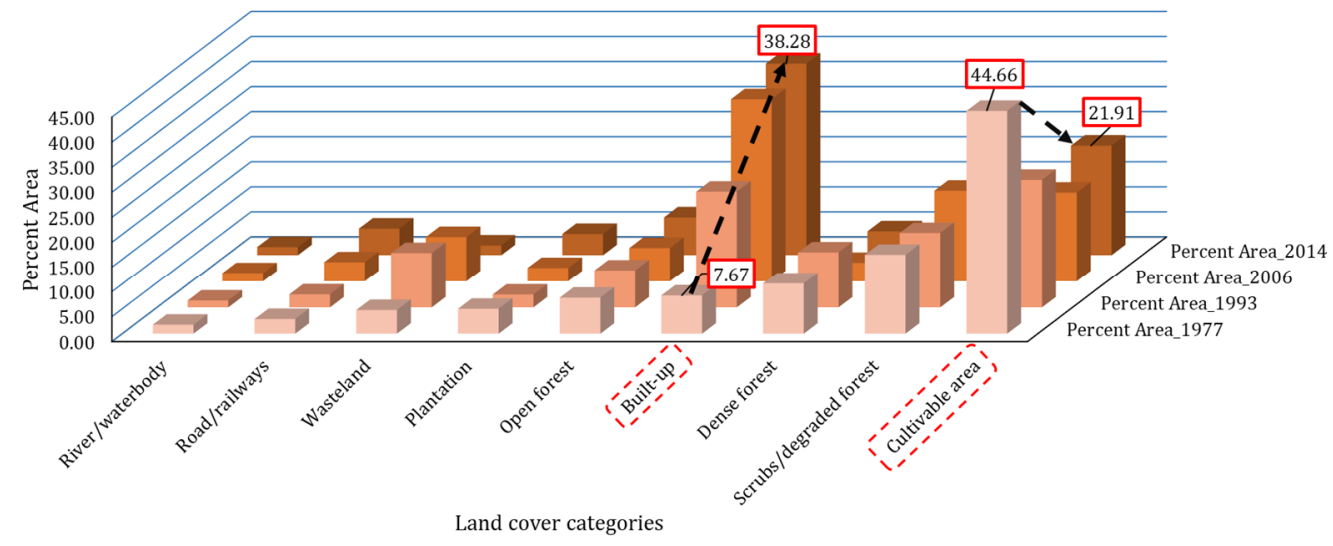

Figure 7. Change in different LULC categories in Delhi from 1977 until 2014.

Table 3. Number of flooding events under different intensity categories from 1963 until 2019, and percent urban area of Delhi at different time periods.

\begin{tabular}{ccccc}
\hline Time Period & $\begin{array}{c}\text { Low } \\
(<\mathbf{2 0 4 . 2 2} \mathbf{~ m})\end{array}$ & $\begin{array}{c}\text { No. of Flooding Events * } \\
\text { Medium } \\
(\mathbf{2 0 4 . 2 2} \mathbf{~ m - 2 0 5 . 4 4 ~} \mathbf{~})\end{array}$ & $\begin{array}{c}\text { High } \\
(>\mathbf{2 0 4 . 4 4} \mathbf{~ m})\end{array}$ & $\begin{array}{c}\text { Percent } \\
\text { Urban Area \# }\end{array}$ \\
\hline $1963-1973$ & 0 & 6 & 5 & - \\
$1974-1981$ & 0 & 3 & 5 & 7.67 \\
$1982-1990$ & 2 & 4 & 3 & - \\
$1991-1999$ & 1 & 4 & 4 & 23.26 \\
$2000-2009$ & 2 & 6 & 2 & 36.44 \\
$2010-2019$ & 1 & 4 & 5 & 38.28 \\
\hline
\end{tabular}

Source: * I\&FC Department; ${ }^{\#}$ Jain et al. 2016. 
Moreover, the urban drainage system constituting the city's 18 major drains has also become inefficient in handling the floods, resulting in their getting overbanked. These drains were already under the immense pressure of the city's effluent discharge, which has reduced their water-holding capacities, resulting in sudden tipping off their banks during flooding surges.

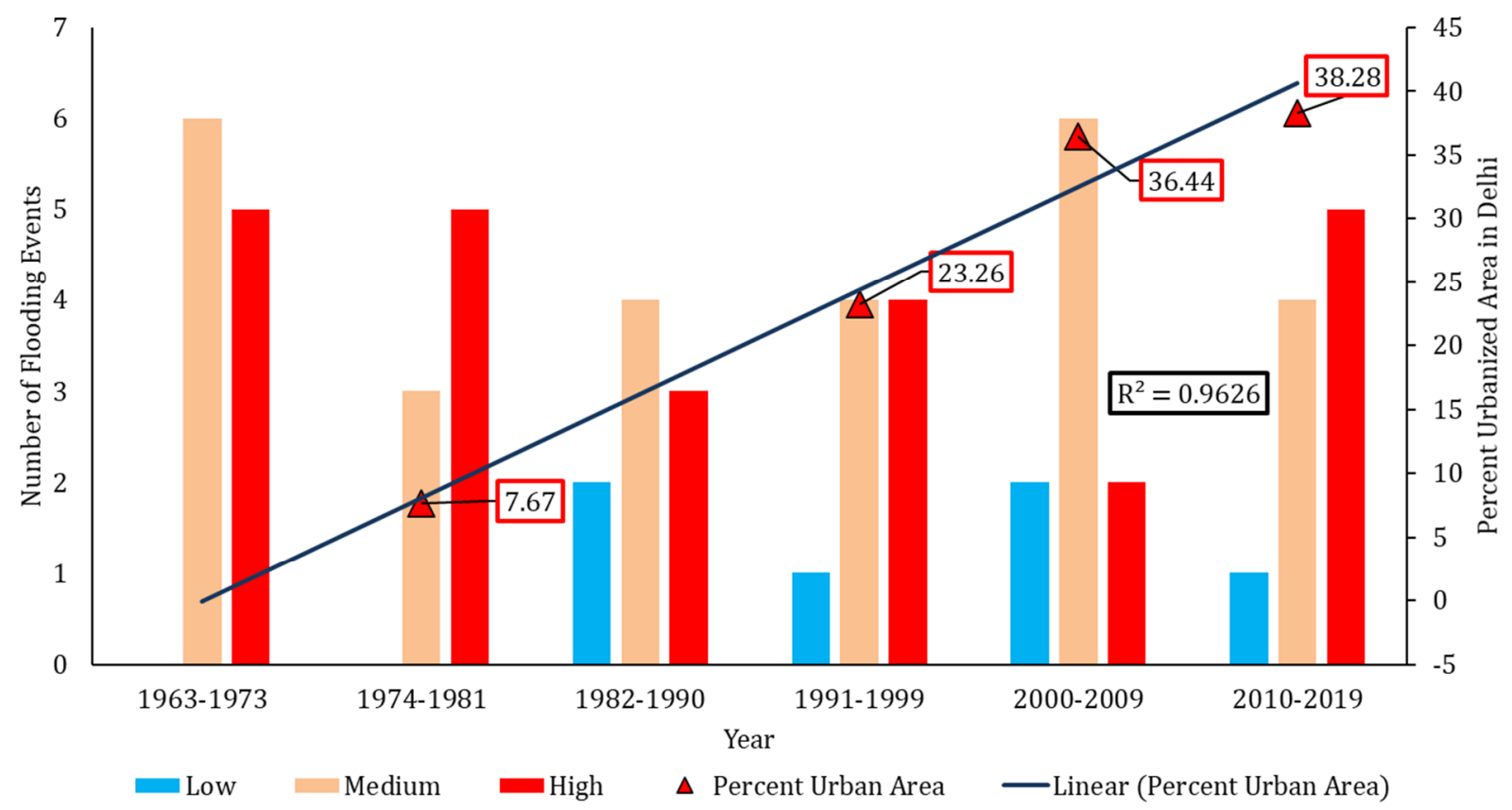

Figure 8. Graph representing the number of flooding events since 1963 against the change in the area under urban class. $\mathrm{R}^{2}=0.96$ for the scatterplot of percent area vs time periods depicts that there has been an enormous increase in the urban area in Delhi since the 1974-1981 period.

The maximum flood inundation extent was evaluated using an integrated remote sensing, GIS, and field-based modeling approach. We aimed to find the spatial extent of the flood when the gauge readings at the Old Delhi Railway gauging station are at $207 \mathrm{~m}$ and $208 \mathrm{~m}$, maximum to date, so that an early warning mechanism is set up for the affected settlements when the gauge readings reach above specific levels. We have used the linear regression model results for forecasting gauge levels at $208 \mathrm{~m}$ using the time precipitation data of the Yamuna catchment. Figure 9a shows the gauge levels of flooding events from 1963 until 2019 with the corresponding rainfall values in the Yamuna catchment. Figure 9b shows the regression plot between the gauge level and rainfall. It has been found that both are positively correlated with Pearson's correlation coefficient equal to 0.62 , indicating a strong positive significant correlation between the two. The linear regression results are shown in Table $4 a, b$ and can be used to forecast gauge levels against the observed rainfall in the catchment. However, it is pertinent to mention that the flow of Yamuna within Delhi is primarily influenced by discharge from the Tajewala Headwork $240 \mathrm{~km}$ upstream. In the event of heavy rain in the catchment area, excess water is released from Tajewala. Depending upon the river flow level downstream, it takes about $48 \mathrm{~h}$ for the Yamuna level in Delhi to rise. The rise in water level also causes a backflow effect on the city's drains. 


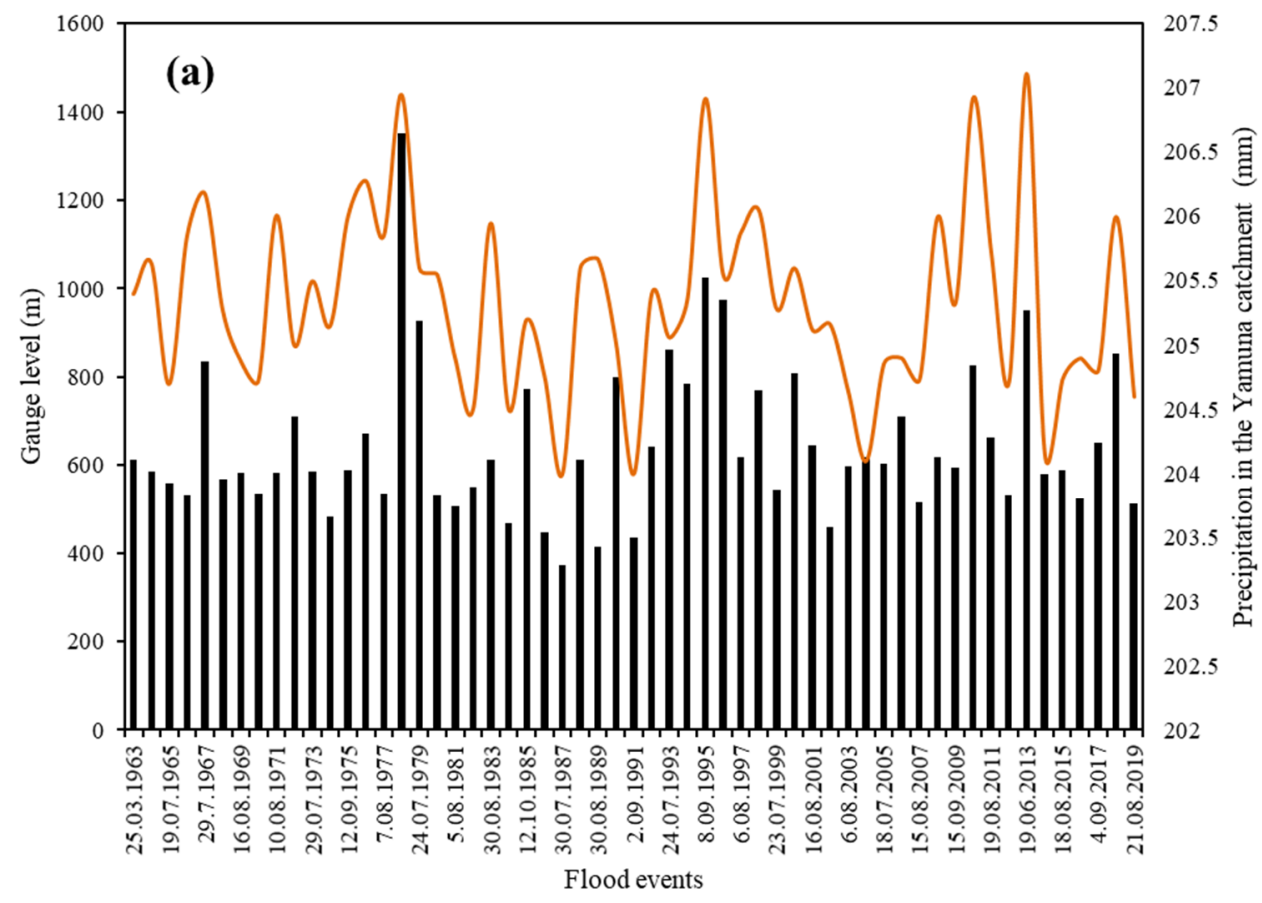

Rainfall (mm) - Gauge level (m)

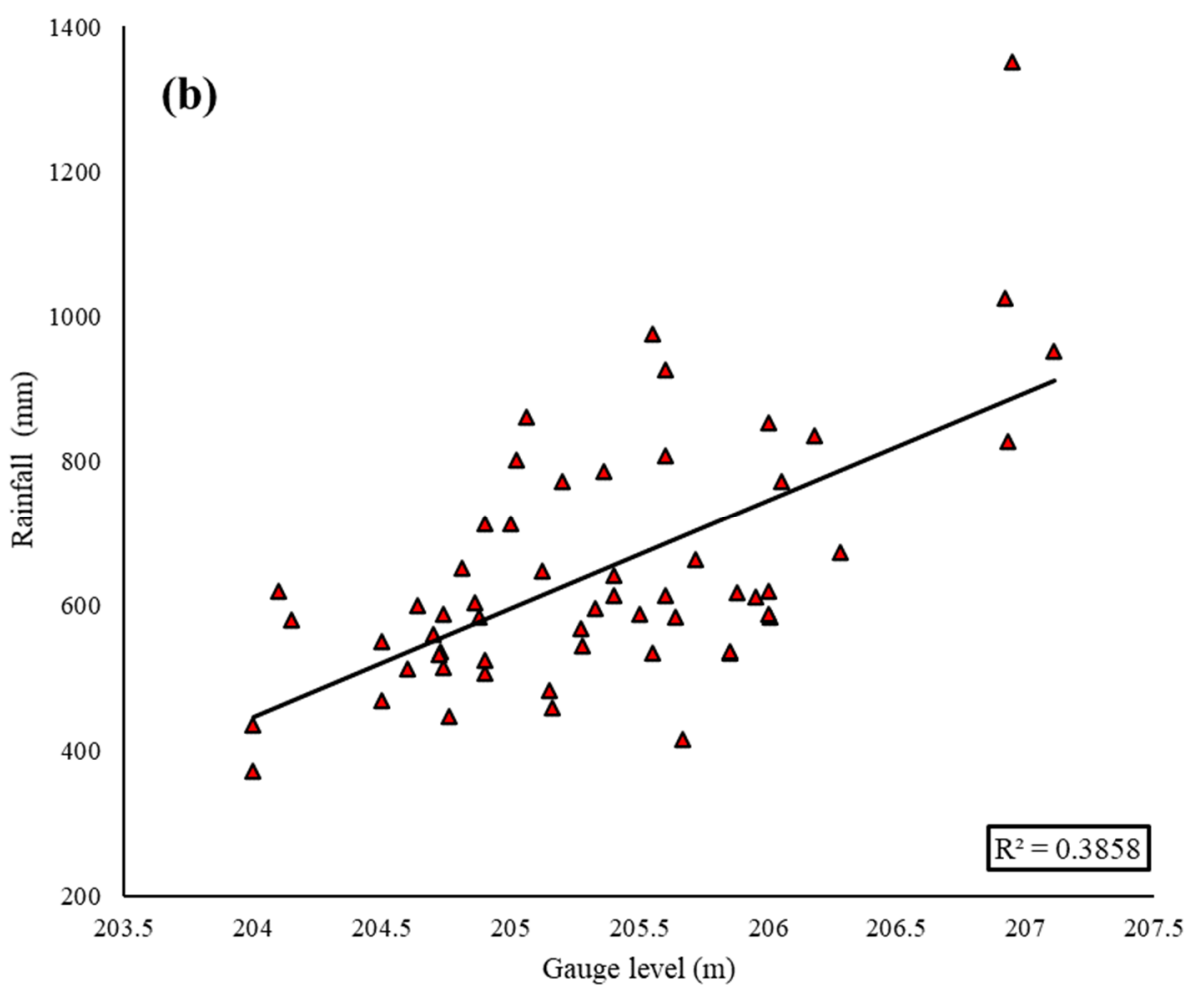

Figure 9. (a) Relationship between time series of catchment precipitation and gauge level. (Source: Irrigation \& Flood Control Department). (b) Linear regression model of the catchment precipitation and gauge level for modeling gauge level in the event of a storm. 
Table 4. (a) Regression Statistics of the linear regression model. (b) Significance of linear regression model.

(a) Regression Statistics of the linear regression model

$\begin{array}{lc}\text { Multiple R } & 0.65 \\ \text { R Square } & 0.41 \\ \text { djusted R Square } & 0.40 \\ \text { Standard Error } & 0.57 \\ \text { Observations } & 56\end{array}$

(b) Significance of linear regression model

\begin{tabular}{cccccccccc} 
& Coefficients & Standard & Error & $t$ Stat & $p$-Value & Lower 95\% & Upper 95\% & Lower 95.0\% & Upper 95.0\% \\
Intercept & 203.70 & 0.2781 & 732.45 & 0.005 & 203.14 & 204.25 & 203.14 & 204.25 \\
613.607 & 0.0025 & 0.00041 & 6.145 & 0.005 & 0.0017 & 0.0033 & 0.0017 & 0.0033 \\
\hline
\end{tabular}

The highest flood level value has been taken from the last 50 years to restrict the flood boundary. It has been categorized into two categories: actual flood value, i.e., $207 \mathrm{~m}$, exceeding flood value, i.e., $208 \mathrm{~m}$ at the Old Delhi Railway gauging station. The flood extent derived was used to generate a risk map. The database created was shared with authorities for decision and planning purposes to help devise strategies during extreme water levels. The resulting maps and data were helpful in municipal planning and emergency action plans during floods (Figures 10-13).

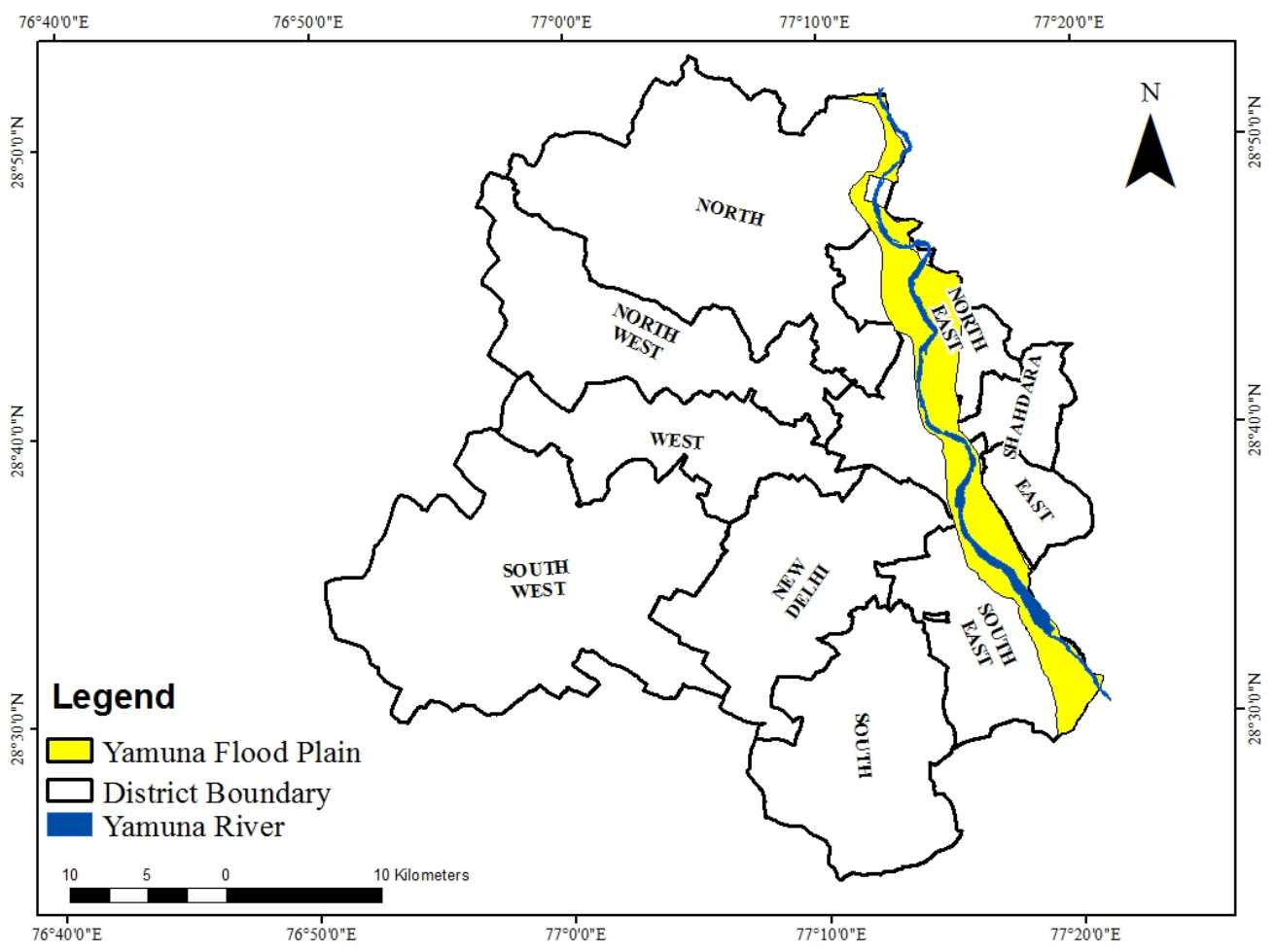

Figure 10. Yamuna River floodplain boundary map of study area. 


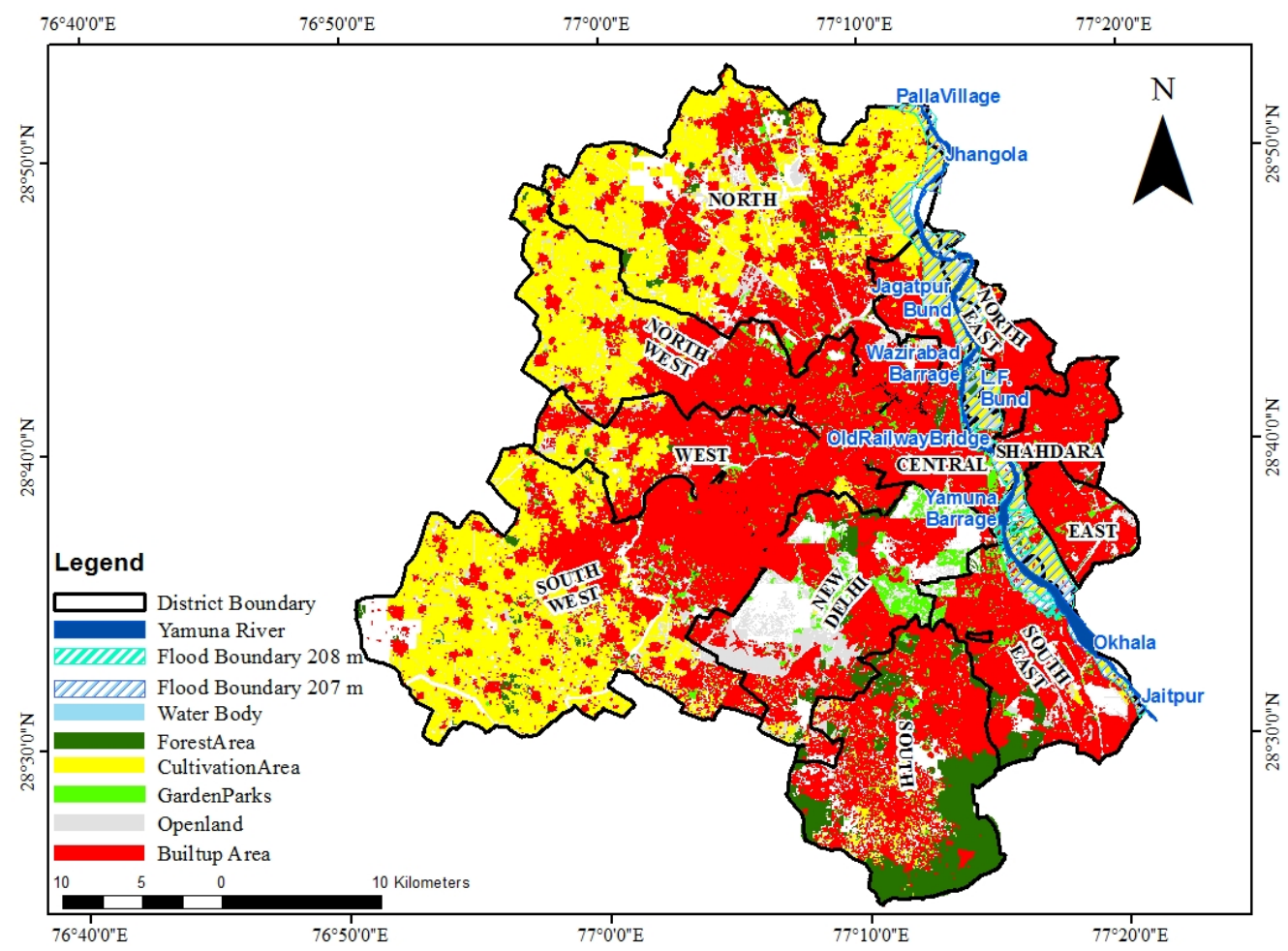

Figure 11. Yamuna River flood boundary map of study area (revised).
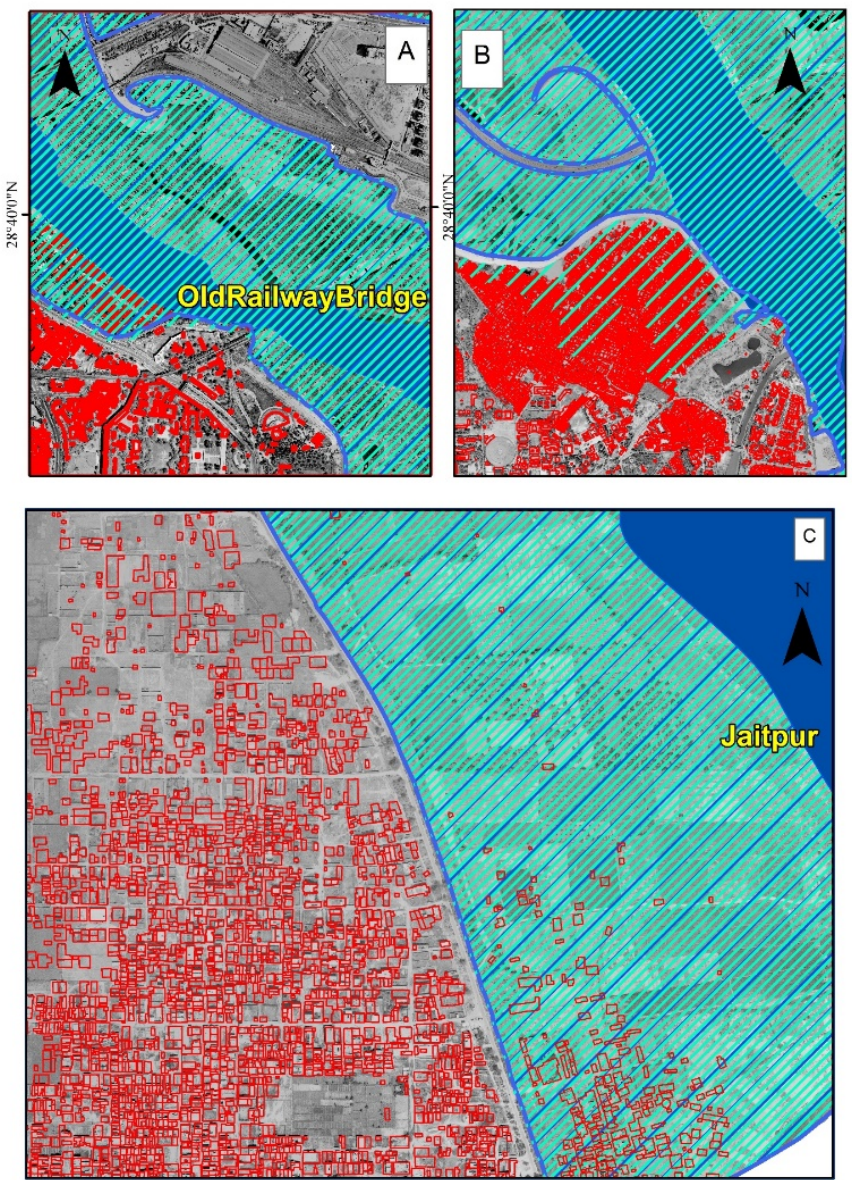

Figure 12. (A) Flood-affected area at the Old Railway Bridge, (B) flood-affected area near Okhla Barrage, and (C) flood-affected area near Jaitpur village. 


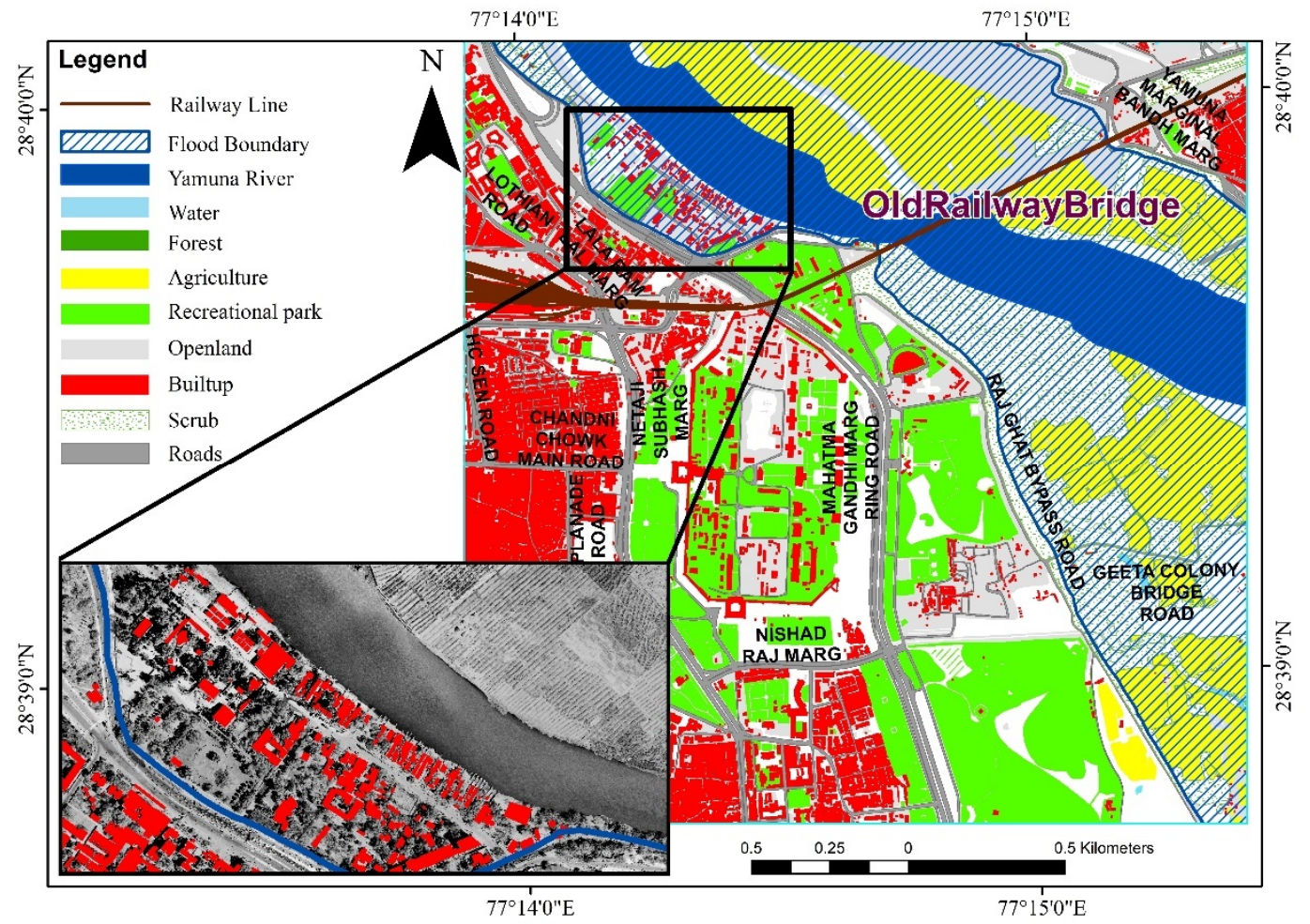

Figure 13. Zoomed in view of flood affected areas.

The results of the total and individual areas affected by the flood are shown in Tables 5-7. The built-up class affected by the flood is $0.88 \mathrm{sq} \mathrm{km}$ at $207 \mathrm{~m}$ and $1.00 \mathrm{sq} \mathrm{km}$ at $208 \mathrm{~m}$ levels.

Table 5. Flood-affected area in $\mathrm{km}^{2}$.

\begin{tabular}{ccc}
\hline Land Use & $\begin{array}{c}\text { Level on 207 m Old Delhi } \\
\text { Railway Bridge }\end{array}$ & $\begin{array}{c}\text { Level on 208 m Old Delhi } \\
\text { Railway Bridge }\end{array}$ \\
\hline Built up & 0.88 & 1.00 \\
Sand Area & 0.02 & 0.027 \\
Barren Land & 3.43 & 2.59 \\
Cultivation Area & 37.87 & 38.12 \\
Scrub Area & 6.16 & 6.22 \\
Vegetation Area & 2.23 & 0.34 \\
\hline
\end{tabular}

Table 6. District flood boundary area (in $\mathrm{km}^{2}$ ) (exceeding flood value for $208 \mathrm{~m}$ at Old Delhi Railway Bridge).

\begin{tabular}{ccc}
\hline District Name & Actual Flood Boundary Area & Built-Up Area \\
\hline Southeast & 10.71 & 0.42 \\
East & 12.01 & 0.20 \\
Shahdara & 1.101 & 0.0002 \\
Central & 16.05 & 0.12 \\
Northeast & 20.84 & 0.24 \\
North & 8.18 & 0.005 \\
Total & 68.89 & 1.00 \\
\hline
\end{tabular}


Table 7. District flood boundary area (in km2) (exceeding flood value for $207 \mathrm{~m}$ at Old Delhi Railway Bridge).

\begin{tabular}{ccc}
\hline District Name & Actual Flood Boundary Area & Built-Up Area \\
\hline Southeast & 9.81 & 0.60 \\
East & 11.83 & 0.20 \\
Shahdara & 1.08 & 0.0002 \\
Central & 15.39 & 0.042 \\
Northeast & 20.84 & 0.024 \\
North & 8.14 & 0.005 \\
Total & 67.09 & 0.88 \\
\hline
\end{tabular}

We have observed that the flood in Delhi NCT is more a consequence of a lousy drainage system than a traditional precipitation-discharge relationship, which is best modeled using hydrodynamic models such as HEC-RAS and others (Figure 14). We propose to evacuate the high-risk zone people to higher grounds as soon as the warning is issued. Prior to any flooding event, there must be policy related to relocation of the settlements of the high-risk zones. Moreover, to tackle the inefficient urban drainage system of the Delhi NCT, periodical removal of silt must be ensured to restore their water holding capacity.

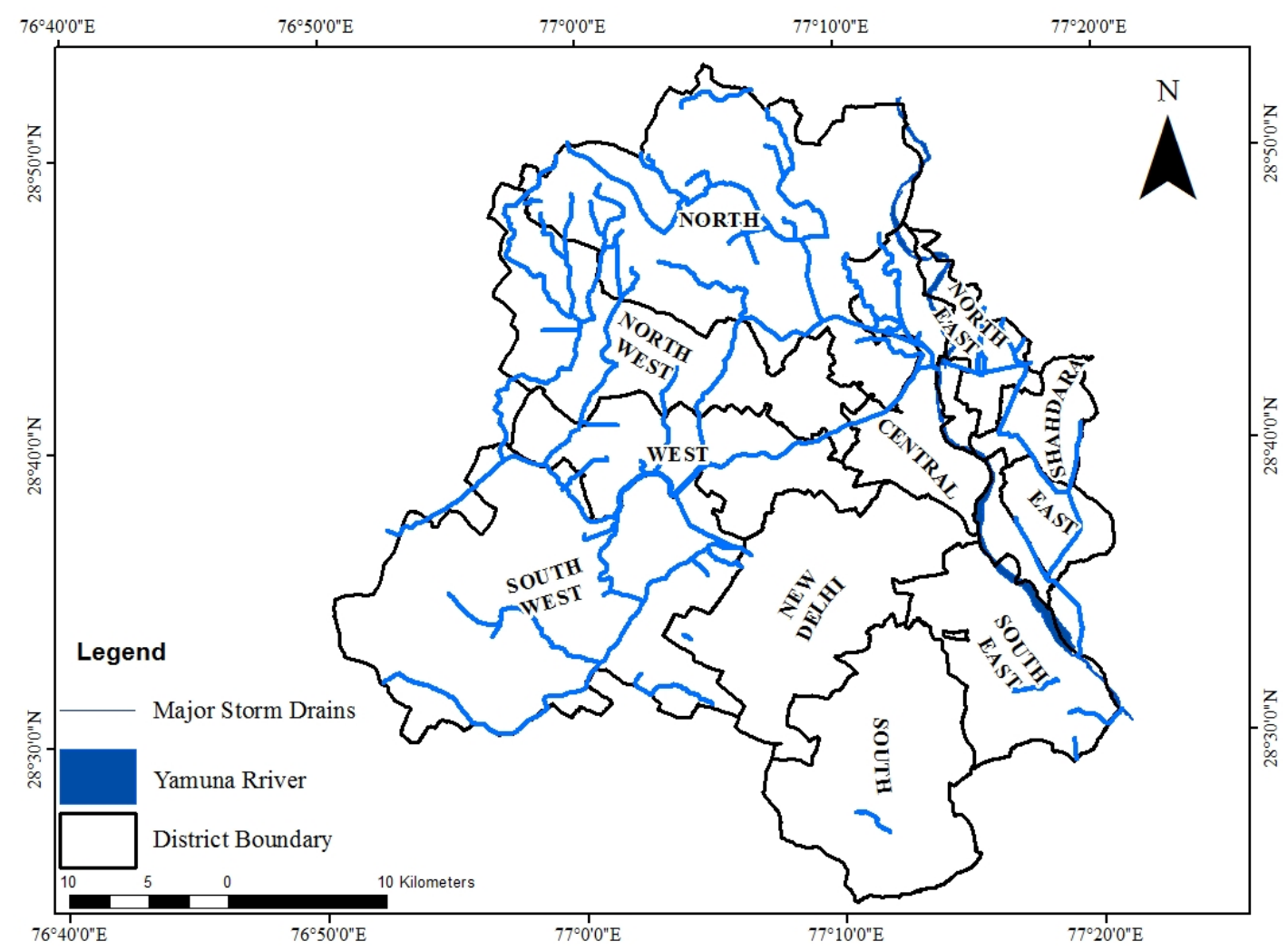

Figure 14. Major storm drain map of the study area (revised).

Perrenial flooding in the Delhi segment of the Yamuna River has a devastating effect on the life and property of the inhabitants, particularly those residing close to the banks. The damage to infrastructure severely affects the economy and, hence, the development of Delhi. There is considerable stress on the floodplain, mainly due to rapid urbanization that has taken place during the past few decades. It is clearly evident from the present study that a large number of colonies in the low-lying areas of Delhi are at a considerable risk of flooding, even during moderate-intensity floods. A combination of structural and nonstructural measures can minimize the risk of Delhi floods. We propose the formulation a 
people-friendly policy for the relocation of vulnerable communities and concrete measures to ensure an efficient urban drainage system.

GIS is ideally suited for planning floodplain management strategies with the help of post-disaster verification of floodplain extents and depths, which was successfully implemented in the present work. The study explored the spatial distribution of flooding, the vulnerability of different assets, particularly concerning buildings, land uses, and flood control work in the Yamuna floodplain in Delhi under extreme flooding scenarios for the national capital of India. A baseline framework was established that could be used to assess the flood disaster risk reduction and to supplement the already existing flood management infrastructure in the study area to help the planners deal with the floods more efficiently.

\section{Limitations and Future Scope}

The present work mapped the areas susceptible to flooding under the most extreme gauge level scenario at the Old Delhi Railway discharge station to date. However, due to data limitations, many aspects of the present work remained untouched, which can be added once the data becomes available. In the context, one of the unexplored problems is the assessment of how the headwater at the Tajewala Barrage could be managed to regulate the entry of flood waters into Delhi (NCT). To address this issue, a water supply and demand scenario between these two locations can be modelled using models like WEAP (Water Evaluation and Planning) [75,76]. The results from this analysis can be used to depict how much extra water during floods can be allocated towards different areas/sectors to save the Delhi NCT from excessive damage. This understanding is also substantiated by the observation from this study that around 38\% variation in river gauge level unexplained during the correlation analysis is actually influenced by an upstream regulation point, i.e., Tajewala Headworks.

Further, in order to better analyze the urban flooding, the Storm Water Management Model (SWMM) can be used to assess the efficiency of the present urban drainage system of Delhi (NCT) [77,78]. The model can simulate storm events and the resulting flooding scenarios and shall help the I\&FC authorities devise an efficient drainage system in the region. This analysis can be further supplemented with the probability analysis of river discharges that shall provide insights into how frequently it surpasses the normal levels.

The fulfillment of these information gaps in the present study shall, in the future, provide a completely different understanding of the Delhi (NCT) flooding process and help the government devise a more comprehensive flood management and mitigation plan.

\section{Conclusions}

The integrated approach of remote sensing, GIS, and field surveys for mapping and modeling current and future flood extents used in this work proved to be very effective for disaster risk mapping and management. This method has an excellent prospect of creating a long-term flood preparedness, risk assessment, and relief management database. This study explored the spatial distributions of flooding and the vulnerability of different assets and supplemented already existing flood forecasting mechanisms in the Yamuna floodplain in Delhi. The Yamuna River has caused serious flood problems in the union territory of Delhi by inundating large areas during flood season. Metro stations, the Akshardham temple, and sports complexes are encroaching on the Yamuna floodplain and are examples of shortsightedness and an invitation to disasters. A baseline framework was established to assess the flood disaster risks and flood risk reduction. The highest flood level value has been taken from the last 50 years to restrict the flood boundary. Further, the linear regression model of time series of precipitation and gauge level records proved essential for forecasting gauge levels in the event of a storm event to formulate an early warning system for preventing losses to life and property in the study area. The result shall also help decision-makers generate flood plain boundaries for carrying adequate risk management policy initiatives. It shall also allow planners to conduct site suitability analysis for prevention and mitigation measures in the face of potential threats. Further, 
the same data will identify building vulnerability due to flooding to improve construction practice. The paper shall also effectively contribute to building a decision support system for planning and mitigating floods. Budgeting (financial impact analysis) for flood-affected areas can be done based on this study.

Author Contributions: Conceptualization, P.T., S.K.S. and G.M.; methodology, S.K.; software, P.T. and G.M.; validation, S.K.S., S.K., G.M. and N.K.; formal analysis, P.T., G.M. and A.P.; investigation, G.M. and S.K.S.; resources, S.K.; data curation, S.K.S. and G.M.; writing-original draft preparation, P.T., G.M. and S.K.S.; writing-review and editing, G.M., N.K. and B.Đ.; visualization, S.K. and G.M.; supervision, S.K. and A.P.; project administration, S.K.S. and S.K.; funding acquisition, B.Đ. All authors have read and agreed to the published version of the manuscript.

Funding: This research, as well as APC costs are covered from the support project for the scientific research from the University North, Koprivnica, Croatia.

Institutional Review Board Statement: Not applicable.

Informed Consent Statement: Not applicable.

Data Availability Statement: Data available upon request to authors.

Acknowledgments: We thank the two anonymous reviewers for critically analyzing this manuscript and suggesting invaluable corrections/additions that have greatly improved the quality and structure of this paper. We further thank the Irrigation and Flood Control (I\&FC) department, Government of Delhi, for the providing the required data. We also thank the Delhi Municipal Corporation (DMC) authorities for providing invaluable insights about the flooding problem currently prevalent in Delhi and the solutions that can be initiated (NCT).

Conflicts of Interest: The authors declare no conflict of interest.

\section{References}

1. Katiyar, V.; Tamkuan, N.; Nagai, M. Near-Real-Time Flood Mapping Using Off-the-Shelf Models with SAR Imagery and Deep Learning. Remote Sens. 2021, 13, 2334. [CrossRef]

2. Moniruzzaman, M.; Thakur, P.K.; Kumar, P.; Ashraful Alam, M.; Garg, V.; Rousta, I.; Olafsson, H. Decadal Urban Land Use/Land Cover Changes and Its Impact on Surface Runoff Potential for the Dhaka City and Surroundings Using Remote Sensing. Remote Sens. 2021, 13, 83. [CrossRef]

3. Meraj, G.; Romshoo, S.A.; Yousuf, A.R.; Altaf, S.; Altaf, F. Assessing the influence of watershed characteristics on the flood vulnerability of Jhelum basin in Kashmir Himalaya. Nat. Hazards 2015, 77, 153-175. [CrossRef]

4. Bera, A.; Taloor, A.K.; Meraj, G.; Kanga, S.; Singh, S.K.; Đurin, B.; Anand, S. Climate vulnerability and economic determinants: Linkages and risk reduction in Sagar Island, India; A geospatial approach. Quat. Sci. Adv. 2021, 4, 100038. [CrossRef]

5. Meraj, G.; Khan, T.; Romshoo, S.A.; Farooq, M.; Rohitashw, K.; Sheikh, B.A. An integrated geoinformatics and hydrological modelling-based approach for effective flood management in the Jhelum Basin, NW Himalaya. Proceedings 2018, 7, 8. [CrossRef]

6. Pandey, A.C.; Singh, S.K.; Nathawat, M.S. Waterlogging and flood hazards vulnerability and risk assessment in Indo Gangetic plain. Nat. Hazards 2010, 55, 273-289. [CrossRef]

7. Supattra, P.; Paramate, H. Internetworking flood disaster mitigation system based on remote sensing and mobile GIS. Geomatics. Nat. Hazards Risk 2020, 11, 1886-1911. [CrossRef]

8. Uddin, K.; Matin, M.A. Potential flood hazard zonation and flood shelter suitability mapping for disaster risk mitigation in Bangladesh using geospatial technology. Prog. Disaster Sci. 2021, 18, 100185. [CrossRef]

9. Merz, B.; Blöschl, G.; Vorogushyn, S.; Dottori, F.; Aerts, J.C.; Bates, P.; Bertola, M.; Kemter, M.; Kreibich, H.; Lall, U.; et al. Causes, impacts and patterns of disastrous river floods. Nat. Rev. Earth Environ. 2021, 10, 1-8. [CrossRef]

10. Berke, P.; Kates, J.; Malecha, M.; Masterson, J.; Shea, P.; Yu, S. Using a resilience scorecard to improve local planning for vulnerability to hazards and climate change: An application in two cities. Cities 2021, 119, 103408. [CrossRef]

11. Brinkmann, K.; Hoffmann, E.; Buerkert, A. Spatial and Temporal Dynamics of Urban Wetlands in an Indian Megacity over the Past 50 Years. Remote Sens. 2020, 12, 662. [CrossRef]

12. Wang, X.; Xie, H. A Review on Applications of Remote Sensing and Geographic Information Systems (GIS) in Water Resources and Flood Risk Management. Water 2018, 10, 608. [CrossRef]

13. Mason, D.C.; Dance, S.L.; Cloke, H.L. Floodwater detection in urban areas using Sentinel-1 and WorldDEM data. J. Appl. Remote Sens. 2021, 15, 032003. [CrossRef]

14. Ismail, E. Flash Flood Hazard Mapping Using Satellite Images and GIS Tools: A case study of Najran City, Kingdom of Saudi Arabia (KSA). Egypt. J. Remote Sens. Space Sci. 2015, 18, 261-278. [CrossRef] 
15. Liu, R.; Chen, Y.; Wu, J.; Gao, L.; Barrett, D.; Xu, T.; Li, L.; Huang, C.; Yu, J. Assessing spatial likelihood of flooding hazard using naïve Bayes and GIS: A case study in Bowen Basin, Australia. Stoch. Environ. Res. Risk Assess. 2016, 30, 1575-1590. [CrossRef]

16. Liu, R.; Chen, Y.; Wu, J.; Gao, L.; Barrett, D.; Xu, T.; Li, X.; Li, L.; Huang, C.; Yu, J. Integrating entropy-based naïve Bayes and GIS for spatial evaluation of flood hazard. Risk Anal. 2017, 37, 756-773. [CrossRef] [PubMed]

17. Chen, Y.; Liu, R.; Barrett, D.; Gao, L.; Zhou, M.; Renzullo, L.; Emelyanova, I. A spatial assessment framework for evaluating flood risk under extreme climates. Sci. Total Environ. 2015, 538, 512-523. [CrossRef]

18. Liu, S.; Liu, R.; Tan, N. A Spatial Improved-kNN-Based Flood Inundation Risk Framework for Urban Tourism under Two Rainfall Scenarios. Sustainability 2021, 5, 2859. [CrossRef]

19. Dhiman, R.; Vishnu, R.; Eldho, R.; Inamdar, A. Flood risk and adaptation in Indian coastal cities: Recent scenarios. Appl. Water Sci. 2019, 9, 5. [CrossRef]

20. Sowmya, K.; John, C.M.; Shrivasthava, N.K. Urban flood vulnerability zoning of Cochin City, southwest coast of India, using remote sensing and GIS. Nat. Hazards 2015, 75, 1271-1286. [CrossRef]

21. Amarnath, G. An algorithm for rapid flood inundation mapping from optical data using a reflectance differencing technique. J. Flood Risk Manag. 2014, 7, 239-250. [CrossRef]

22. Mazumder, S.K. Determination of waterway under a bridge in Himalayan Region-Some Case Studies. J. Indian Roads Congr. 2009.

23. Pramanik, N.; Panda, R.K.; Sen, D. One dimensional hydrodynamic modeling of river flow using DEM extracted river crosssections. Water Resour. Manag. 2010, 24, 835-852. [CrossRef]

24. Timbadiya, P.V.; Patel, P.L.; Porey, P.D. Calibration of channel and flood plain roughness using $1 \mathrm{~d} / 2 \mathrm{~d}$ integrated hydrodynamic model: A study of surat city on lower tapi river. In Proceedings of the 10th International Conference on Hydroscience and Engineering, Orlando, FL, USA, 4-7 November 2012; pp. 4-7.

25. Doiphode, S.L.; Oak, R.A. Dynamic Flood Routing and Unsteady Flow Modeling: A Case Study of Upper Krishna River. IJAET 2012, 3, 55-59.

26. Sankhua, R.N.; Sathe, B.K.; Srivastava, A.K. A Case Study on Dynamic Wave Routing and Unsteady Flood Modelling of Part of Krishna Basin with HEC-RAS. India Water Week Water, Energy and Food Security. 2012. Available online: https:// indiawaterweek.thewaternetwork.com/storage/TFX\%5CDocumentBundle\%5CEntity\%5CDocument-n4buNw YaAKy1 H0H2WbUErQ/FPssPyCjnA0AFVCVCYX4Ww / file/A\%20Case\%20Study\%20on\%20Dynamic\%20Wave\%20Routing\%20 and \%20Unsteady\%20Flood\%20Modelling\%20of\%20Part\%20of\%20Krishna\%20Basin\%20With\%20Hecras.pdf (accessed on 17 November 2021).

27. Vijay, R.; Sargoankar, A.; Gupta, A. Hydrodynamic simulation of river Yamuna for riverbed assessment: A case study of Delhi region. Environ. Monit. Assess. 2007, 130, 381-387. [CrossRef]

28. Vijay, R.; Sargaonkar, A.; Gupta, A. A hydrodynamic approach to address Yamuna riverbed development in Delhi. Can. J. Civ. Eng. 2009, 36, 1155-1163. [CrossRef]

29. Husain, A.; Sharif, M.; Ahmad, M.L. Simulation of Floods in Delhi Segment of River Yamuna Using HEC-RAS. Am. J. Water Resour. 2018, 6, 162-168.

30. Kumar, M.; Sharif, M.; Ahmed, S. Flood Estimation in River Yamuna (India) Using Peak-Over-Threshold Method. ISH 2018, 26, 291-300.

31. Kumar, M.; Sharif, M.; Ahmed, S. Flood risk management strategies for national capital territory of Delhi, India. ISH J. Hydraul. Eng. 2019, 25, 248-259. [CrossRef]

32. Biswas, A.K.; Saklani, U.; Tortajada, C. Truth about urban flooding: Cities like Mumbai get inundated regularly due to administrative apathy, not climate change. Times India Mumbai Ed. 2017, 31, 2017.

33. Gupta, S. Impact of Floods in Delhi; Climatrans: New Delhi, India, 2017.

34. Gupta, K. Challenges in developing urban flood resilience in India. Philos. Trans. R. Soc. A Math. Phys. Eng. Sci. 2020, 378, 20190211. [CrossRef] [PubMed]

35. Singh, O.; Kumar, M. Flood occurrences, damages, and management challenges in India: A geographical perspective. Arab. J. Geosci. 2017, 10, 102. [CrossRef]

36. Rafiq, F.; Ahmed, S.; Ahmad, S.; Khan, A.A. Urban floods in India. Int. J. Sci. Eng. Res. 2016, 7, 721-734.

37. Madan, A.; Routray, J.K. Institutional framework for preparedness and response of disaster management institutions from national to local level in India with focus on Delhi. Int. J. Disaster Risk Reduct. 2015, 14, 545-555. [CrossRef]

38. Gosain, A.K.; Khandelwal, P.K.; Kulshrestha, S. Urban floods: Case study of Delhi. Disaster Dev. $2009,3,15$.

39. Ghosh, S.K.; Gupta, H.N.; Johri, A.P. A comparative hydro meteorological study of the historical floods in the Yamuna river. Mausam 1982, 33, 197-206.

40. Prashar, S.; Shaw, R.; Takeuchi, Y. Assessing the resilience of Delhi to climate-related disasters: A comprehensive approach. Nat. Hazards 2012, 64, 1609-1624. [CrossRef]

41. Ghosh, S.; Duggal, Y.; Roy, N.; Mehra, H. Rainfall in the upper Yamuna catchment in relation to moisture transport over Delhi. Mausam 1987, 38, 93-96.

42. Parida, Y.; Saini, S.; Chowdhury, J.R. Economic growth in the aftermath of floods in Indian states. Environ. Dev. Sustain. 2020, 23, 535-561. [CrossRef]

43. Mall, R.K.; Singh, R.; Gupta, A.; Singh, R.S.; Rathore, L.S. Water Resources and Climate Change: An Indian perspective. Curr. Sci. 2006, 90, 1610-1626. 
44. Parida, Y. Economic impact of floods in the Indian states. Environ. Dev. Econ. 2019, 25, 267-290. [CrossRef]

45. Gupta, S.; Javed, A.; Datt, D. Economics of Flood Protection in India. InFlood Problem and Management in South Asia; Springer: Dordrecht, The Netherlands, 2003; pp. 199-210.

46. Ahmed, M.L.; Sharif, M.; Shakeel, M. Analysis of Discharge and Gauge Level Data at Old Railway Bridge, Delhi. In Proceedings of the International Conference on Artificial Intelligence, Energy and Manufacturing Engineering (ICAEME'2014), Kuala Lumpur, Malaysia, 9 June 2014.

47. De, U.S.; Singh, G.P.; Rase, D.M. Urban flooding in recent decades in four mega cities of India. J. Ind. Geophys. Union 2013, 17, 153-165.

48. India, P. Census of India 2011 Provisional Population Totals; Office of the Registrar General and Census Commissioner: New Delhi, India, 2011.

49. Jain, M.; Dimri, A.P.; Niyogi, D. Urban Sprawl Patterns and Processes in Delhi from 1977 to 2014 Based on Remote Sensing and Spatial Metrics Approaches. Earth Interact. 2016, 20, 1-29. [CrossRef]

50. Jain, M.; Taubenböck, H.; Namperumal, S. Seamless urbanisation and knotted city growth: Delhi Metropolitan Region. In Proceedings of the Real Corp, Essen, Germany, 18-20 May 2011; pp. 853-862.

51. Singh, R.; Salunkhe, U.; Patil, V.V. Nature and determinants of migration: Insights from NSSO data in three states of India. Migr. Lett. 2021, 18, 261-280. [CrossRef]

52. Sutoris, P. Elitism and its challengers: Educational development ideology in postcolonial India through the prism of film, 1950-1970. Int. J. Educ. Dev. 2018, 60, 1-9. [CrossRef]

53. Han, Y.; Qin, R.; Huang, X. Assessment of dense image matchers for digital surface model generation using airborne and spaceborne images-An update. Photogramm. Record 2020, 35, 58-80. [CrossRef]

54. Doğruluk, M.; Yanalak, M. Object-based modelling and accuracy assessment of Gordion tumuli using very high-resolution stereo satellite images. Int. J. Remote Sens. 2021, 42, 7239-7269. [CrossRef]

55. Meraj, G.; Romshoo, S.A.; Yousuf, A.R. Geoinformatics approach to qualitative forest density loss estimation and protection cum conservation strategy-a case study of Pir Panjal range, J.\&K.; India. Int. J. Curr. Res. Rev. 2012, 4, 47-61.

56. Meraj, G.; Singh, S.K.; Kanga, S.; Islam, N. Modeling on comparison of ecosystem services concepts, tools, methods and their ecological-economic implications: A review. Model. Earth Syst. Environ. 2021, 1-20. [CrossRef]

57. Meraj, G.; Kanga, S.; Kranjčić, N.; Đurin, B.; Singh, S.K. Role of Natural Capital Economics for Sustainable Management of Earth Resources. Earth 2021, 2, 622-634. [CrossRef]

58. Elmhirst, R.; Middleton, C.; Resurrección, B.P. Migration and floods in Southeast Asia: A mobile political ecology of vulnerability, resilience and social justice. In Living with Floods in a Mobile Southeast Asia; Routledge: Abingdon, UK, 2017 ; pp. 1-21.

59. Venkatappa, M.; Sasaki, N.; Han, P.; Abe, I. Impacts of droughts and floods on croplands and crop production in Southeast Asia-An application of Google Earth Engine. Sci. Total Environ. 2021, 795, 148829. [CrossRef] [PubMed]

60. Middleton, C.; Elmhirst, R.; Chantavanich, S. (Eds.) Living with Floods in a Mobile Southeast Asia: A Political Ecology of Vulnerability, Migration and Environmental Change; Routledge: Abingdon, UK, 2017.

61. Tembata, K.; Takeuchi, K. Floods and Exports: An Empirical Study on Natural Disaster Shocks in Southeast Asia. Econ. Disasters Clim. Chang. 2018, 3, 39-60. [CrossRef]

62. Chen, A.; Giese, M.; Chen, D. Flood impact on Mainland Southeast Asia between 1985 and 2018-The role of tropical cyclones. J. Flood Risk Manag. 2020, 13, e12598. [CrossRef]

63. Hochrainer-Stigler, S.; Schinko, T.; Hof, A.; Ward, P.J. Adaptive risk management strategies for governments under future climate and socioeconomic change: An application to riverine flood risk at the global level. Environ. Sci. Policy 2021, 125, 10-20. [CrossRef]

64. García-Ayllón, S. New Strategies to Improve Co-Management in Enclosed Coastal Seas and Wetlands Subjected to Complex Environments: Socio-Economic Analysis Applied to an International Recovery Success Case Study after an Environmental Crisis. Sustainability 2019, 11, 1039. [CrossRef]

65. Katusiime, J.; Schütt, B. Integrated Water Resources Management Approaches to Improve Water Resources Governance. Water 2020, 12, 3424. [CrossRef]

66. Tellman, B.; Sullivan, J.A.; Kuhn, C.; Kettner, A.J.; Doyle, C.S.; Brakenridge, G.R.; Erickson, T.A.; Slayback, D.A. Satellite imaging reveals increased proportion of population exposed to floods. Nature 2021, 596, 80-86. [CrossRef]

67. Bhola, P.K.; Leandro, J.; Disse, M. Building hazard maps with differentiated risk perception for flood impact assessment. Nat. Hazards Earth Syst. Sci. 2020, 20, 2647-2663. [CrossRef]

68. Allen, S.; Ballesteros-Canovas, J.; Randhawa, S.; Singha, A.; Huggel, C.; Stoffel, M. Translating the concept of climate risk into an assessment framework to inform adaptation planning: Insights from a pilot study of flood risk in Himachal Pradesh, Northern India. Environ. Sci. Policy 2018, 87, 1-10. [CrossRef]

69. Mustafa, A.; Szydłowski, M. Application of different building representation techniques in HEC-RAS 2-D for urban flood modeling using the Toce River experimental case. Peer J. 2021, 9, e11667. [CrossRef]

70. Attari, M.; Hosseini, S.M. A simple innovative method for calibration of Manning's roughness coefficient in rivers using a similarity concept. J. Hydrol. 2019, 575, 810-823. [CrossRef]

71. Chang, C.-H.; Lee, H.; Hossain, F.; Basnayake, S.; Jayasinghe, S.; Chishtie, F.; Saah, D.; Yu, H.; Sothea, K.; Du Bui, D. A model-aided satellite-altimetry-based flood forecasting system for the Mekong River. Environ. Model. Softw. 2018, 112, 112-127. [CrossRef]

72. Pal, S.; Singha, P. Analyzing sensitivity of flood susceptible model in a flood plain river basin. Geocarto Int. 2021, 1-35. [CrossRef] 
73. Yusoff, I.M.; Ramli, A.; Al-Kasirah, N.A. Geospatial Data and Technology Application Towards Managing Flood Disaster in the Context of Industrial Revolution 4.0 (IR4. 0). J. Adv. Geospat. Sci. Technol. 2021, 1, 38-69.

74. Jain, M.; Dawa, D.; Mehta, R.; Dimri, A.P.; Pandit, M. Monitoring land use change and its drivers in Delhi, India using multi-temporal satellite data. Model. Earth Syst. Environ. 2016, 2, 1-14. [CrossRef]

75. Amin, A.; Iqbal, J.; Asghar, A.; Ribbe, L. Analysis of Current and Future Water Demands in the Upper Indus Basin under IPCC Climate and Socio-Economic Scenarios Using a Hydro-Economic WEAP Model. Water 2018, 10, 537. [CrossRef]

76. Tena, T.M.; Mwaanga, P.; Nguvulu, A. Impact of Land Use/Land Cover Change on Hydrological Components in Chongwe River Catchment. Sustainability 2019, 11, 6415. [CrossRef]

77. Babaei, S.; Ghazavi, R.; Erfanian, M. Urban flood simulation and prioritization of critical urban sub-catchments using SWMM model and PROMETHEE II approach. Phys. Chem. Earth Parts A/B/C 2018, 105, 3-11. [CrossRef]

78. Zeng, Z.; Yuan, X.; Liang, J.; Li, Y. Designing and implementing an SWMM-based web service framework to provide decision support for real-time urban stormwater management. Environ. Model. Softw. 2020, 135, 104887. [CrossRef] 